\title{
Field Scale Studies on the Spatial Variability of Soil Quality Indicators in Washington State, USA
}

\author{
Jeffrey L. Smith ${ }^{1}$ and Jonathan J. Halvorson ${ }^{2}$ \\ ${ }^{1}$ USDA-Agricultural Research Service, 215 Johnson Hall, Washington State University, Pullman, WA 99164-6421, USA \\ ${ }^{2}$ USDA-Agricultural Research Service, 1224 Airport Road, Beaver, WV 25813, USA
}

Correspondence should be addressed to Jeffrey L.Smith, jlsmith@wsu.edu

Received 21 October 2010; Accepted 26 January 2011

Academic Editor: Marco Trevisan

Copyright (C 2011 J. L. Smith and J. J. Halvorson. This is an open access article distributed under the Creative Commons Attribution License, which permits unrestricted use, distribution, and reproduction in any medium, provided the original work is properly cited.

\begin{abstract}
Arable lands are needed for sustainable agricultural systems to support an ever-growing human population. Soil quality needs to be defined to assure that new land brought into crop production is sustainable. To evaluate soil quality, a number of soil attributes will need to be measured, evaluated, and integrated into a soil-quality index using the multivariable indicator kriging (MVIK) procedure. This study was conducted to determine the spatial variability and correlation of indicator parameters on a field scale with respect to soil quality and suitability for use with MVIK. The variability of the biological parameters decreased in the order of respiration > enzyme assays and $\mathrm{qCO}_{2}>$ microbial biomass $\mathrm{C}$. The distribution frequency of all parameters except respiration were normal although the spatial distribution across the landscape was highly variable. The biological parameters showed little correlation with each other when all data points were considered; however, when grouped in smaller sections, the correlations were more consistent with observed patterns across the field. To accurately assess soil quality, and arable land use, consideration of spatial and temporal variability, soil conditions, and other controlling factors must be taken into account.
\end{abstract}

\section{Introduction}

The challenge of feeding 9 billion people by the year 2050 is intimidating. Multiple strategies are needed to meet this challenge. Strategies include reducing human population growth, decreasing protein consumption, increasing crop and animal production, and increasing the agricultural land base for production. While some food staples (crops and livestock) are increasing, others are static or decreasing [1]. Currently food production for 6 billion people occurs on $13 \%$ of the global land surface [2].

The current strategical focus has been on increasing yields and increasing the agricultural land base $[3,4]$. The challenge to moving these strategies forward is to evaluate (1) new land for the ability to produce crops and (2) the soil's resilience and resistance to degrade over time from agriculture management. Thus, the concept of soil quality needs to be developed to evaluate and manage land developed for increased crop production $[5,6]$. In a global context, soil quality affects not only soil productivity but is also a significant factor governing environmental quality, human and animal health, and food safety and quality [7]. Soil quality of current and future agricultural land is of similar importance to humankind as air and water quality; thus, it is apparent that simply protecting soil quality by slowing soil degradation or maintaining the current level of soil health will not provide the soil quality that will be needed for future generations. Soil quality must be improved as well.

To properly assess soil quality, appropriate soil indicators or properties must be identified. These indicators must be quantified on a local and landscape basis as a means for making small-scale and regional management decisions. Indicators proposed to asses soil quality are diverse and include chemical, physical, and biological variables as well as descriptive terms [8]. Once the indicators are identified, methods need to be developed to integrate the indicators into a soil quality index. This integration procedure will require the use of information from all indicators as well as their interactions [9]. Several years ago, a procedure was developed to spatially evaluate soil quality. The procedure, multiple 
variable indicator kriging (MVIK), categorizes numerous variables based on specific criteria producing a probability that an "area" or "soil" meets qualified standards [9]. For example, criteria can be developed and parameters measured and integrated to evaluate if a land area is suitable for development of irrigated agriculture. The MVIK method has been used to map the distribution of soil nutrients [10], define zones of soil pollutants [11], evaluate chemical health risks of groundwater [12], evaluate soil quality indices $[6,13]$, classify soil degradation in agricultural lands [14], and assess groundwater quality for irrigated agriculture [15].

The underlying principle of MVIK is the spatial variability of indicator parameters across the landscape. In this study, we have chosen several chemical and microbiological parameters that have been shown to be important in agriculture and are considered good indicators of soil quality $[8,9]$. These indicators, not meant to be inclusive, include microbial biomass, respiration, metabolic quotient $\left(\mathrm{qCO}_{2}\right)$, dehydrogenase, and phosphatase enzyme activity as well as $\mathrm{pH}$, organic carbon $(\% \mathrm{C})$, and electrical conductivity (EC). We explore the spatial variability and relationships of indicators across a small landscape that was intensively sampled. Knowing the range and spatial variability criteria for MVIK, we can develop a system for the evaluation of suitable land for crop production.

\section{Materials and Methods}

2.1. Soil Collection. Soil samples were taken from a slightly north-sloping agricultural field in Southeastern Washington State, USA. The field had previously been cropped to winter wheat (Triticum aestivum L.). The soil is a Palouse silt loam classified as a fine-silty mixed, superactive, Pachic Ultic Haploxeroll having an average organic C content of $1.5 \%$ and a total $\mathrm{N}$ content of $0.15 \%$.

The climate of this region is characterized by cold wet winters and hot dry summers with $80 \%$ of the annual 500 $\mathrm{mm}$ of precipitation being received between October and March. Soil samples (220) were collected in October (Fall) from an area of approximately $0.5 \mathrm{ha}(50 \times 110 \mathrm{~m})$. The sampling design was a regular $10 \times 10 \mathrm{~m}$ grid with smaller sampling distances randomly placed throughout the larger grid. At each sampling location, approximately $200 \mathrm{~g}$ of soil was collected from the top $10 \mathrm{~cm}$, placed in a plastic bag and stored at $4^{\circ} \mathrm{C}$ until analyzed.

The 220 soil samples were analyzed for total organic $\mathrm{C}, \mathrm{pH}$, electrical conductivity (EC), microbial biomass $\mathrm{C}$ (SIRC), basal respiration, phosphatase (PNP), dehydrogenase (TPF), and calculated metabolic quotient $\left(\mathrm{qCO}_{2}\right)$. Analyses were done in triplicate.

2.2. Biological Assays. Microbial biomass was assayed using the substrate induced respiration (SIR) method developed by Anderson and Domsch [16]. Triplicate $10 \mathrm{~g}$ (dry weight) samples of soil were weighed into $40 \mathrm{ml}$ glass vials, brought to $20 \%$ moisture $(\mathrm{w} / \mathrm{w})$, covered and kept in the dark for 7 days at $23.5 \pm 0.5^{\circ} \mathrm{C}$. After the preincubation, each sample was amended with a saturating level of 600 ug glucose
$(240 \mathrm{mg} \mathrm{C}) \mathrm{g}^{-1}$ soil, bringing the soil moisture content to $25 \%(\mathrm{w} / \mathrm{w})(-30 \mathrm{kPa})$. Water only was added to each control sample also bringing the soil to $25 \%(\mathrm{w} / \mathrm{w})(-30 \mathrm{kPa})$. All tubes were flushed with hydrated air and capped with a septum. Headspace $\mathrm{CO}_{2}$ was measured from each vial at 3 and $24 \mathrm{~h}$ by injecting $0.2 \mathrm{ml}$ of headspace in to a gas chromatograph. Microbial biomass carbon (SIRC) was calculated using the equation published by Anderson and Domsch [16]. Soil respiration (RESP) rate was calculated as the average rate of $\mathrm{CO}_{2}$ production per hour from the control samples (only water added).

Soil dehydrogenase and phosphatase activity was measured using the modified technique of Bolton et al. [17]. The substrate for dehydrogenase activity was 2,3,5triphenyltetrazolium $(3 \% \mathrm{w} / \mathrm{v})$ and $\mathrm{p}$-nitrophenol phosphate for phosphatase activity. Enzyme assays were made in triplicate on moist soil (10 g dry weight) and reported for dehydrogenase as $10^{-5} \mu \mathrm{mol}$ triphenylformazan $\mathrm{g}^{-1} \mathrm{~min}^{-1}$ (TPF) and for phosphatase as $10^{-2} \mu \mathrm{mol}$ p-nitrophenol $\mathrm{g}^{-1} \min ^{-1}$ (PNP).

Metabolic quotient $\left(\mathrm{qCO}_{2}\right)$ is defined as the basal respiration per unit of microbial biomass in units of $\mu \mathrm{g} \mathrm{CO}_{2}$ $\mathrm{C} \mu \mathrm{g}^{-1}$ biomass- $\mathrm{Ch}^{-1}$ and was calculated from the control sample respiration rate at the end of the incubation period divided by the SIRC biomass [18].

2.3. Chemical Analysis. Total organic C was measured in triplicate on each of the 220 soil samples by a wet oxidation method [19]. The pH and electrical conductivity (EC) measurements were made on saturated pastes of soil $(1: 1 \mathrm{w} / \mathrm{w}$, soil : water).

2.4. Statistical Methods. Summary statistics were calculated for the 220 samples including mean, median, and standard deviation (SD), coefficient of variation (\%CV), and skewness. In addition, Pearson correlation coefficients were calculated for untransformed data. We also constructed maps of the spatial distributions for each individual variable over the 0.5 ha area from untransformed data using a weighted least squares algorithm. Every point at an unsampled location is calculated by a weighted quadratic multiple regression on all the points [20].

\section{Results}

3.1. Chemical and Biological Indicators. Univariate statistics for measured soil properties are shown in Table 1. For the chemical properties the mean and median values were similar and the skewness values were low to moderate (EC). The relatively high variability of total C $(\% \mathrm{CV}=39.6)$ on this landscape was related to spatial patterns. We observed lower values on the eastern $25 \%$ of the field (see Figure 2). However, in general, the \%CVs for chemical properties on a landscape area are typical [21].

All biological variables, except microbial respiration, also showed similar mean and median values with low to moderate skewness (Table 1). The sample distribution for respiration exhibited significant skewness (4.35) due to a few 
TABLE 1: Univariate statistics for measured soil properties $(n=220)$. Total C, pH, EC: electrical conductivity; SIRC: microbial biomass C by substrate-induced respiration; RESP: nonamended soil respiration; PNP: phosphatase activity; TPF, dehydrogenase activity and qCO ${ }_{2}$, metabolic quotient.

\begin{tabular}{|c|c|c|c|c|c|c|c|c|}
\hline & \multicolumn{3}{|c|}{ Chemical Properties } & \multicolumn{5}{|c|}{ Biological Properties } \\
\hline & $\begin{array}{c}\mathrm{C} \\
(\%) \\
\end{array}$ & $\mathrm{PH}$ & $\begin{array}{c}\mathrm{EC} \\
\left(\mathrm{dS} \mathrm{m}^{-1}\right)\end{array}$ & $\begin{array}{c}\text { SIRC } \\
\left(\mathrm{mg} \mathrm{C} \mathrm{kg}^{-1}\right)\end{array}$ & $\begin{array}{c}\text { RESP } \\
\left(\mathrm{mg} \mathrm{C} \mathrm{kg}^{-1} \mathrm{~h}^{-1}\right)\end{array}$ & $\begin{array}{c}\text { PNP } \\
\left(\mu \mathrm{mol} \mathrm{g}^{-1} \min ^{-1} \times 10^{-2}\right)\end{array}$ & $\begin{array}{c}\text { TPF } \\
\left(\mu \mathrm{mol} \mathrm{g}^{-1} \min ^{-1} \times 10^{-5}\right)\end{array}$ & $\begin{array}{l}\mathrm{qCO}_{2}{ }^{\mathrm{a}} \\
\left(\times 10^{-3}\right)\end{array}$ \\
\hline Mean & 1.70 & 5.14 & 2.13 & 642 & 1.65 & 3.91 & 4.33 & 1.04 \\
\hline Median & 1.76 & 5.12 & 2.00 & 620 & 1.41 & 3.85 & 4.36 & 1.04 \\
\hline SD & 0.67 & 0.24 & 0.68 & 198 & 1.17 & 1.30 & 1.57 & 0.44 \\
\hline$\% \mathrm{CV}$ & 39.6 & 4.70 & 32.0 & 31 & 71.0 & 33.2 & 36.1 & 42.4 \\
\hline Skewness & -0.22 & 0.12 & 1.81 & 1.5 & 4.35 & 0.53 & 0.12 & 0.62 \\
\hline Minimum & 0.35 & 4.56 & 0.95 & 227 & 0.53 & 1.13 & 0.75 & 0.12 \\
\hline Maximum & 2.97 & 5.74 & 5.79 & 1694 & 9.44 & 9.21 & 7.96 & 2.61 \\
\hline
\end{tabular}

${ }^{\mathrm{a}} \mu \mathrm{g} \mathrm{CO} \mathrm{CO}_{2}-\mathrm{C} \mathrm{g}^{-1} \mathrm{~h}^{-1} / \mu \mathrm{g}$ biomass $\mathrm{C} \mathrm{g}^{-1}$ soil.

high outlier values. This outlier effect is confirmed by the 75 th percentile value $\left(1.76 \mathrm{mg} \mathrm{kg}^{-1}\right)$ being close to the mean value of $1.65 \mathrm{mg} \mathrm{kg}^{-1}$ (data not shown) and also reflected in the $\mathrm{CV}$ of $71 \%$. Microbial biomass $\mathrm{C}$ ranged from 227 to $1694 \mathrm{mg} \mathrm{C} \mathrm{kg}^{-1}$ soil with a CV of $31 \%$, typical for this biological parameter [22]. Values for metabolic quotient $\left(\mathrm{qCO}_{2}\right)$ ranged over an order of magnitude, from 0.12 to 2.61 $\times 10^{-3} \mu \mathrm{g} \mathrm{CO}_{2}-\mathrm{C} \mu \mathrm{g}^{-1}$ biomass-C $\mathrm{h}^{-1}$, with a $\mathrm{CV}$ of $42 \%$. The enzyme assays, phosphatase and dehydrogenase, showed similar variation among samples with CVs of 33 and 36\%, respectively.

3.2. Spatial Mapping and Correlation. The distribution of electrical conductivity (EC), dehyrogenase (TPF), and respiration (RESP) over the 0.5 ha sampling area are depicted in Figure 1. Most sample respiration rates were near the overall

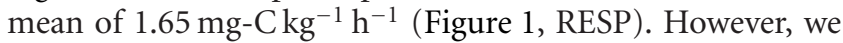
also observed a zone of higher values in the 60-70 m Easting area and a few other elevated values at about $85-100 \mathrm{~m}$ Easting. In contrast, dehyrogenase activity was distributed throughout the field in zones of high and low activity (Figure 1, TPF), much different than what might have been predicted from the univariate statistics (Table 1) [23, 24]. Highest TPF activity was observed from the $0 \mathrm{~m}$ to $20 \mathrm{~m}$ Easting, the portion of the field that also had the lowest respiration values. Dehyrogenase activity was lower than the mean at random locations mostly in the north half of the field between 30 and $100 \mathrm{~m}$ Easting. Values of EC, an important soil variable since soluble salts may affect microbial and enzyme activity $[25,26]$ were generally similar to the overall field mean except in the $110 \mathrm{~m}$ easting area and in a few locations randomly distributed across the field (Figure 1, EC). The trend in EC was generally opposite of TPF and, in some areas, seemed to be similar in pattern to RESP.

Figure 2 shows the spatial distribution of total C (\%C), $\mathrm{pH}$, and microbial biomass (SIRC). Microbial biomass was characterized by a fairly uniform spatial distribution with many values close to the field mean (Figure 2 SIRC). However, we also observed a significant area of the field

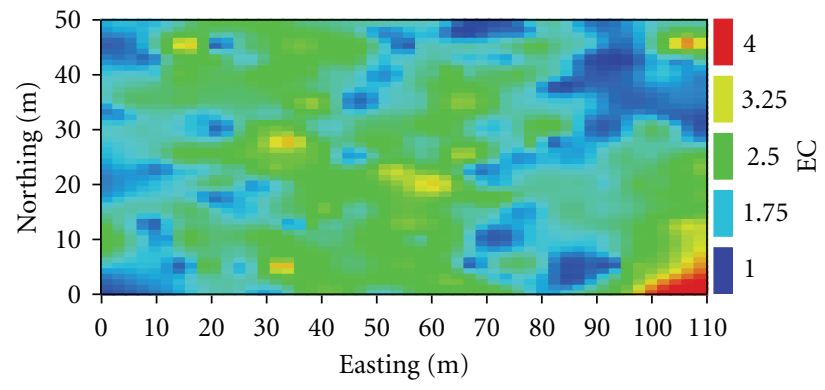

(a)

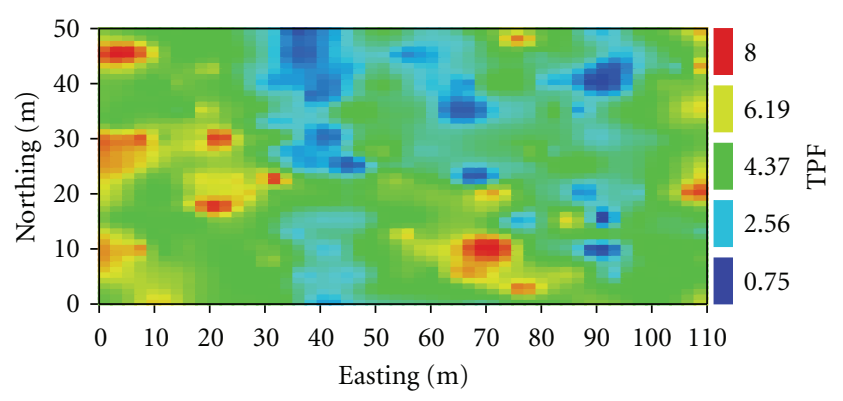

(b)

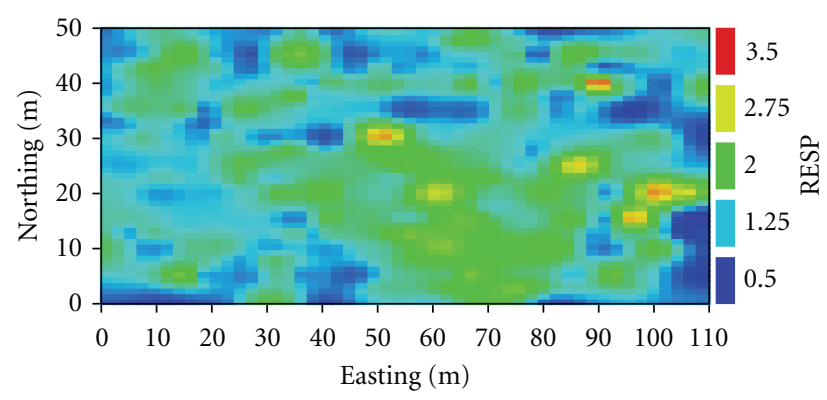

(c)

Figure 1: Interpolated spatial maps, over the 110 by $50 \mathrm{~m}$ field, of electrical conductivity (EC), dehydrogenase (TPF), and microbial respiration (RESP). Units are the same as Table 1. 


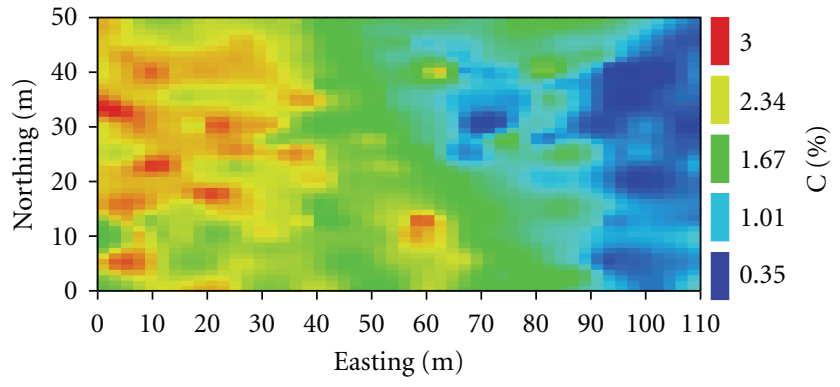

(a)

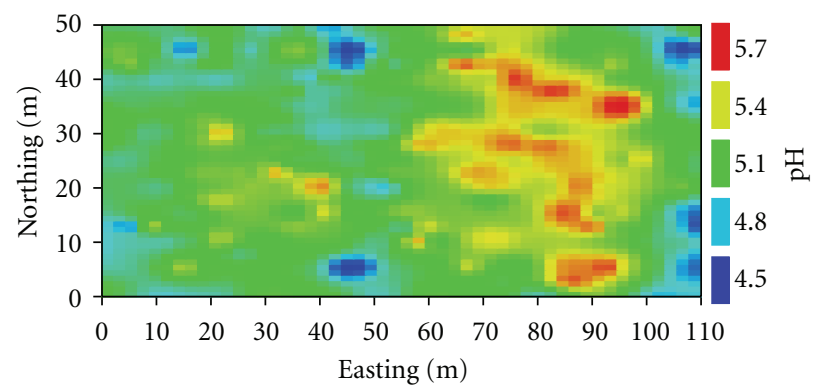

(b)

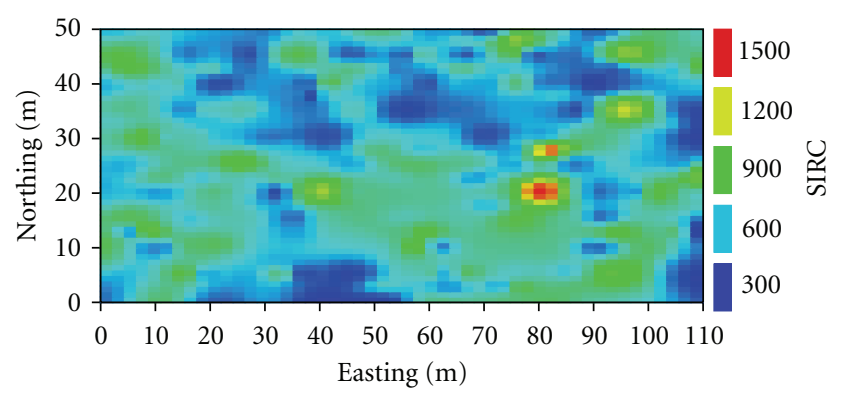

(c)

Figure 2: Interpolated spatial maps, over the 110 by $50 \mathrm{~m}$ field, of $\% \mathrm{C}, \mathrm{pH}$ and microbial biomass $\mathrm{C}$ (SIRC). Units are the same as Table 1.

with values $50 \%$ greater than the mean (green). Soil $\mathrm{pH}$ was less evenly spatially distributed across the field than SIRC (Figure $2 \mathrm{pH}$ ). We observed a zone with relatively high values of $\mathrm{pH}$ between 60 and $100 \mathrm{~m}$ Easting. Lower values of $\mathrm{pH}$ in the eastern edge of the field also coincided with a decrease in SIRC and \%C (Figure $2 \% \mathrm{C}$ ). Total $\mathrm{C}$ was distributed with highest concentrations in the west half of the field and lowest concentrations in the east. However, the grading from high to low concentration was not smooth, and the field appears to be divided into two patches. Values near the overall field average (green) occurred mostly in a relatively narrow band with a NW-SW orientation, near the center of the field.

Table 2 provides the Pearson correlation coefficients $(r)$ for the measured soil properties. We calculated $r$ for two spatial scales, full field or subfield. Full field calculations represent an overall $r$ value based on all 220 data points. Subfield calculations were based on the data from each of four $27.5 \mathrm{~m} \mathrm{~W}$ to $\mathrm{E}$ subsections of the field from 0 to
$110 \mathrm{~m}$. Analyses of the entire field generally showed poor correlation's between variables except between RESP and $\mathrm{qCO}_{2}$ and SIRC and TPF (Table 2). Transformation $\left(\log _{10}\right)$ the data did not improve the overall correlation's with the only increase due to normalizing RESP.

Separate analyses of the $27.5 \mathrm{~m}$ subfields revealed areas of relatively high and low correlation obscured at the scale of the entire field. For example, the full field correlation coefficient of SIRC and RESP was $0.15(n=220, P<.05)$; however, these two variables were significantly and positively correlated in two subfields lying between 0 and $55 \mathrm{~m}$ Easting, section of the field, $(0.48, n=55, P<.05$ and $.54, n=55, P<$ $.05)$, respectively. In a more extreme example, the overall field correlation of SIRC and PNP was $0.02(n=220, P<.05)$, while correlation coefficients in the subfields varied: near 0 in the 0 to $27.5 \mathrm{~m}$ section of the field, slightly positive in the 27.5 to $55 \mathrm{~m}$ subfield, slightly negative in the 55.0 to $82.5 \mathrm{~m}$ subfield, and significantly positive in the 82.5 to $110 \mathrm{~m}$ subfield.

By accounting for this intrafield heterogeneity, the correlations between variables were more similar to the qualitative, visual analysis of Figures 1 and 2. For example, RESP and EC exhibited some positive correlation (0.29, $n=55, P<.05$ ), in the 0 to $27.5 \mathrm{~m}$ Easting subfield (Table 2, Figure 1). However, in the subfield located from 27.5 to $55.0 \mathrm{~m}$, where EC was increasing, the correlation coefficient decreased to $0.10(n=51, P \leq .05)$ (Figure 1$)$. In the east half of the field (55+m Easting), correlation between RESP and EC became increasingly negative $(-0.14, n=55$, $P<.05$ and $-0.18, n=53, P<.05)$ due to opposing spatial gradients shown in Figure 1. Soil microbial biomass was uncorrelated with $\% \mathrm{C}$ over the entire field (Table 2, Figure 2); however, SIRC was significantly correlated with $\mathrm{pH}$ in all except in the 55.0 to $82.5 \mathrm{~m}$ subfield (Table 2) also suggested by Figure 2 which shows SIRC as constant over the landscape and $\mathrm{pH}$ as increasing.

\section{Discussion}

The objectives of developing a method to evaluate soil quality include (1) the ability to monitor changes in the soil over time and be able to quantify the direction and rate of change, (2) evaluation of the time rate of change in soil quality due to specific management in both the short and long term, and (3) the ability to detect patterns of soil quality at different spatial and temporal scales. To meet these objectives the evaluation methodology, such as MVIK, must be based on sensitive indicators of change in soil quality that are stable and predictable with respect to other soil properties such that comparisons between different locations and between different time periods can be made.

Several biological indicators of soil quality have been proposed because they are thought to be integrative variables, sensitive to changes in soil degradation or improvement [2730]. However, we are interested in mapping soil quality on the landscape level to monitor change or implement remediation, and there are several problems associated with the use of only biological indicators over field to landscape scales.

First, biological indicators are likely to be more variable in time and space than chemical or physical parameters and 
TABle 2: Pearson correlation $(r)$ matrix correlating chemical and biological soil parameters on a subfield and full field basis (whole field $n=220$, subfield $n=50$ to 55$)$. Values in red are significant correlations where $.01<P<.05 \%$ probability level.

\begin{tabular}{|c|c|c|c|c|c|c|c|c|c|c|c|c|c|c|}
\hline & $\% \mathrm{C}$ & & $\mathrm{pH}$ & & EC & & SIRC & & RESP & & PNP & & TPF & \\
\hline & Subfield & Full field & & & & & & & & & & & & \\
\hline $\mathrm{pH}$ & 0.02 & -0.21 & & & & & & & & & & & & \\
\hline & 0.21 & & & & & & & & & & & & & \\
\hline & -0.39 & & & & & & & & & & & & & \\
\hline & 0.10 & & & & & & & & & & & & & \\
\hline EC & -0.18 & -0.01 & -0.29 & -0.35 & & & & & & & & & & \\
\hline & 0.20 & & 0.01 & & & & & & & & & & & \\
\hline & 0.34 & & -0.36 & & & & & & & & & & & \\
\hline & 0.07 & & -0.54 & & & & & & & & & & & \\
\hline SIRC & -0.01 & -0.01 & 0.39 & 0.31 & -0.04 & -0.07 & & & & & & & & \\
\hline & -0.02 & & 0.4 & & 0.27 & & & & & & & & & \\
\hline & 0.02 & & 0.09 & & -0.12 & & & & & & & & & \\
\hline & -0.04 & & 0.32 & & -0.13 & & & & & & & & & \\
\hline RESP & -0.11 & -0.17 & 0.14 & 0.2 & 0.29 & -0.09 & 0.48 & 0.15 & & & & & & \\
\hline & 0.06 & & 0.37 & & 0.10 & & 0.54 & & & & & & & \\
\hline & 0.10 & & -0.21 & & -0.14 & & -0.05 & & & & & & & \\
\hline & -0.06 & & 0.27 & & -0.18 & & 0.17 & & & & & & & \\
\hline PNP & 0.16 & 0.32 & -0.01 & 0.14 & 0.15 & 0.08 & -0.05 & 0.02 & 0.20 & -0.01 & & & & \\
\hline & 0.23 & & 0.65 & & 0.27 & & 0.28 & & 0.30 & & & & & \\
\hline & 0.01 & & 0.04 & & 0.17 & & -0.25 & & 0.01 & & & & & \\
\hline & -0.16 & & 0.3 & & -0.13 & & 0.33 & & 0.11 & & & & & \\
\hline TPF & 0.14 & 0.23 & 0.37 & -0.02 & -0.16 & 0.02 & 0.38 & 0.22 & 0.03 & 0.04 & -0.28 & -0.05 & & \\
\hline & 0.07 & & 0.3 & & 0.32 & & 0.33 & & 0.26 & & 0.13 & & & \\
\hline & 0.31 & & -0.17 & & -0.06 & & 0.18 & & 0.28 & & 0.15 & & & \\
\hline & 0.08 & & -0.28 & & 0.23 & & 0.12 & & -0.05 & & 0.07 & & & \\
\hline $\mathrm{qCO}_{2}$ & 0.01 & -0.01 & -0.43 & -0.11 & 0.01 & 0.04 & -0.06 & -0.29 & 0.45 & 0.52 & 0.16 & 0.13 & -0.07 & -0.17 \\
\hline & 0.12 & & -0.07 & & -0.16 & & -0.21 & & 0.4 & & -0.01 & & -0.08 & \\
\hline & 0.09 & & -0.12 & & -0.04 & & -0.3 & & 0.73 & & 0.14 & & 0.09 & \\
\hline & 0.03 & & 0.06 & & -0.03 & & 0.12 & & 0.68 & & -0.17 & & -0.03 & \\
\hline
\end{tabular}

may also be influenced by these parameters [21]. Second, univariate statistics of biological indicators may be of limited use in the context of evaluating soil quality, because they only characterize a system at the overall scale and do not account for spatial patterns [23]. Finally, even if we account for the spatial and temporal variability of biological indicators, the precise relationship between the amount of a particular biological indicator and it's functional characteristics has yet to be determined [31].

These problems can become critical when using the MVIK procedure to evaluate specific criteria. The MVIK procedure uses cutoff values to determine if a criteria has been met, thus if indicators vary greatly in time, the cutoff value may not be stable and land evaluation may change.

The coefficient of variation for the biological variables measured in this study ranged from $31 \%$ for microbial biomass-C and $30 \%$ to $40 \%$ for the enzyme assays to $71 \%$ for soil respiration. Rochette et al. [24] found respiration measurements in a 1 ha field (average 50 sampling points) to have a CV ranging from $25 \%$ to $69 \%$ over the growing season. Bonmati et al. [25] found the $\mathrm{CV}$ for enzymes ranged from 28 to $60 \%$ in a small field $(<0.1 \mathrm{ha})$. This is in contrast to many chemical and physical parameters that typically have a CV in the range of $5 \%$ to $25 \%$ on a spatial basis. While mean values or the relative ranking of variability may not change, actual estimates of statistical dispersion (e.g., standard deviation) will be affected by the size of the sampling unit especially for soil properties with strongly skewed distributions [32].

Understanding the spatial distribution of chemical and physical indicators of soil quality is likely to be important for corroborating biological data and necessary to help to explain the spatial variability of biological parameters. For example, Figure 2 shows areas of high and low concentrations of three variables occurring simultaneously in a single field. These distinct areas maybe caused by secondary or 
tertiary factors affecting the primary variable of interest. Greater correlation between soil quality indicators in some sections of the field (Table 2) suggests the factors controlling these variables change over the landscape. For example, unlike the rest of the field, SIRC and $\mathrm{pH}$ were uncorrelated in the 55 to $82 \mathrm{~m}$ Easting section of the field (Table 2). Since the values of SIRC were distributed, on the average, similarly across the entire field, the lower correlation is likely due to increasing $\mathrm{pH}$ values in this section of the field seen in Figure 2. The gradient of $\mathrm{pH}$ across the field may have been related to patterns of $\mathrm{NO}_{3}$ and soil moisture content, which decrease from $\mathrm{W}$ to $\mathrm{E}$ across the field (data not presented). These two soil variables, individually or in combination, may have influenced the increase in $\mathrm{pH}$, and thus its correlation with microbial biomass. Thus, successful use of biological indicators for soil quality analysis will require an understanding their spatial variability as well as that of any underlying factors that might affect this variability.

Our data further illustrate that while the overall univariate distribution of a biological parameter may be normal for a field-size sample unit (Table 1), the variable may be distributed in zones of high and low concentrations within the field (i.e., TPF, Figure 1). Thus the full field mean value may be of little value for guiding management decisions. It would be impossible to manage this field to increase its biological potential based on univariate statistics alone. In order to be useful, we are required to sample in a manner that will allow us to identify and delineate the significant spatial patterns within the field. Contour maps for each soil parameter of interest are desirable but require more sampling and analysis meaning greater expense.

Two other aspects of soil quality indicators can affect land evaluation even using the MVIK procedure. Firstly, evaluating soil quality based on the quantity of a biological indicator assumes that laboratory analyses accurately represent conditions in the field. Secondly, a critical assumption is that the relationship between the quantity of a biological indicator and its activity is well understood and predictable. Yet, little attempt has been made to distinguish between these two facets of soil quality.

Thus based on this study we suggest that soil sampling for soil quality analysis using biological indicators should be conducted when the soils are between 50 to $70 \%$ of field capacity $(-30 \mathrm{kPa})$, during mild temperature regimes (Fall or late Spring) and that enough samples be taken that contour maps can be developed. Other chemical data should be collected at the same time, such as $\mathrm{pH}$ and electrical conductivity, to provide collaborative information for the soil quality assessment. Biological indicators of soil quality are spatially variable; however, they are also sensitive indicators, thus with proper analysis and interpretation they will enhance our development of a soil quality index.

That biological indicators of soil quality should vary across the landscape or during the course of a season is neither novel nor surprising. This is why we developed the MVIK procedure to smooth the variability into a probably that can be used to define good soil quality or good arable land. However, the more stable the data used in the MVIK procedure the better the prediction of arable land. With the spatial variability information on an area basis we can use procedures such as MVIK to evaluate the probably that a new land base will be sustainable for agricultural production.

\section{References}

[1] H. C. J. Godfray, J. R. Beddington, I. R. Crute et al., "Food security: the challenge of feeding 9 billion people," Science, vol. 327, no. 5967, pp. 812-818, 2010.

[2] J. D. Glover, J. P. Reganold, L. W. Bell et al., "Increased food and ecosystem security via perennial grains," Science, vol. 328, no. 5986, pp. 1638-1639, 2010.

[3] Anonomous, "Investing in soils," Nature Geoscience, vol. 3, p. 295, 2010.

[4] Anonomous, "How to feed a hungry world," Nature, vol. 466, pp. 531-532, 2010.

[5] S. S. Andrews, D. L. Karlen, and C. A. Cambardella, “The soil management assessment framework: a quantitative soil quality evaluation method," Soil Science Society of America Journal, vol. 68, no. 6, pp. 1945-1962, 2004.

[6] F. Bastida, A. Zsolnay, T. Hernández, and C. García, "Past, present and future of soil quality indices: a biological perspective," Geoderma, vol. 147, no. 3-4, pp. 159-171, 2008.

[7] J. F. Parr, R. I. Papendick, S. B. Hornick, and R. E. Meyer, "Soil quality: attributes and relationship to alternative and sustainable agriculture," American Journal of Alternative Agriculture, vol. 7, no. 1-2, pp. 5-11, 1992.

[8] J. W. Doran and T. B. Parkin, "Defining and assessing soil quality," in Defining Soil Quality for a Sustainable Environment, J. W. Doran, D. C. Coleman, D. F. Bezdicek, and B. A. Stewart, Eds., pp. 3-21, Soil Science Society of America, Madison, Wis, USA, 1994.

[9] J. L. Smith, J. L. Halvorson, and R. I. Papendick, "Using multiple-variable indicator kriging for evaluating soil quality," Soil Science Society of America Journal, vol. 57, no. 3, pp. 743749, 1993.

[10] F. Han, J. Zheng, W. Hu, F. Du, and X. C. Zhang, "Spatial variability and distribution of soil nutrients in a catchment of the Loess Plateau in China," Acta Agriculturae Scandinavica Section B, vol. 60, no. 1, pp. 48-56, 2010.

[11] H. J. Chu, Y. P. Lin, C. S. Jang, and T. K. Chang, "Delineating the hazard zone of multiple soil pollutants by multivariate indicator kriging and conditioned Latin hypercube sampling," Geoderma, vol. 158, no. 3-4, pp. 242-251, 2010.

[12] J. J. Lee, C. S. Jang, S. W. Wang, and C. W. Liu, "Evaluation of potential health risk of arsenic-affected groundwater using indicator kriging and dose response model," Science of the Total Environment, vol. 384, no. 1-3, pp. 151-162, 2007.

[13] Y. Qi, J. L. Darilek, B. Huang, Y. Zhao, W. Sun, and Z. Gu, "Evaluating soil quality indices in an agricultural region of Jiangsu Province, China," Geoderma, vol. 149, no. 3-4, pp. 325-334, 2009.

[14] N. Diodato and M. Ceccarelli, "Multivariate indicator Kriging approach using a GIS to classify soil degradation for Mediterranean agricultural lands," Ecological Indicators, vol. 4, no. 3, pp. 177-187, 2004.

[15] C. S. Jang, S. K. Chen, and L. Ching-Chieh, "Using multiplevariable indicator kriging to assess groundwater quality for irrigation in the aquifers of the Choushui River alluvial fan," Hydrological Processes, vol. 22, no. 22, pp. 4477-4489, 2008.

[16] J. P. E. Anderson and K. H. Domsch, "A physiological method for the quantitative measurement of microbial biomass in 
soils," Soil Biology and Biochemistry, vol. 10, no. 3, pp. 215221, 1978.

[17] H. Bolton Jr., L. F. Elliott, R. I. Papendick, and D. F. Bezdicek, "Soil microbial biomass and selected soil enzyme activities: effect of fertilization and cropping practices," Soil Biology and Biochemistry, vol. 17, no. 3, pp. 297-302, 1985.

[18] J. L. Smith, "Cycling of nitrogen through microbial activity," in Effects on Soil Quality, J.L. Hatfield and B.A. Stewart, Eds., Soil Biology, pp. 91-120, CRC Press, Boca Raton, Fla, USA, 1994.

[19] J. D. Snyder and J. A. Trofymow, "A rapid accurate wet oxidation diffusion procedure for determining organic and inorganic carbon in plant and soil samples," Communications in Soil Science \& Plant Analysis, vol. 15, no. 5, pp. 587-597, 1984.

[20] SPSS, SYSTAT 11.0 Statistics, SPSS, Chicago, Ill, USA, 2004.

[21] J. J. Halvorson, J. L. Smith, and R. I. Papendick, "Issues of scale for evaluating soil quality," Journal of Soil and Water Conservation, vol. 52, no. 1, pp. 26-30, 1997.

[22] J. L. Smith and E. A. Paul, "The significance of soil microbial biomass estimations," in Soil Biochemistry, J. M. Bollag and G. Stotzkey, Eds., vol. 6, pp. 357-396, Marcel Dekker, New York, NY, USA, 1990.

[23] R. E. Rossi, D. J. Mulla, A. G. Journel, and E. H. Franz, "Geostatistical tools for modeling and interpreting ecological spatial dependence," Ecological Monographs, vol. 62, no. 2, pp. 277-314, 1992.

[24] P. Rochette, R. L. Desjardins, and E. Pattey, "Spatial and temporal variability of soil respiration in agricultural fields," Canadian Journal of Soil Science, vol. 71, no. 2, pp. 189-196, 1991.

[25] M. Bonmati, B. Ceccanti, and P. Nanniperi, "Spatial variability of phosphatase, urease, protease, organic carbon and total nitrogen in soil," Soil Biology and Biochemistry, vol. 23, no. 4, pp. 391-396, 1991.

[26] R. García-Ruiz, V. Ochoa, M. B. Hinojosa, and J. A. Carreira, "Suitability of enzyme activities for the monitoring of soil quality improvement in organic agricultural systems," Soil Biology and Biochemistry, vol. 40, no. 9, pp. 2137-2145, 2008.

[27] F. Zvomuya, H. H. Janzen, F. J. Larney, and B. M. Olson, "A long-term field bioassay of soil quality indicators in a semiarid environment," Soil Science Society of America Journal, vol. 72, no. 3, pp. 683-692, 2008.

[28] T. M. Nissen and M. M. Wander, "Management and soilquality effects on fertilizer-use efficiency and leaching," Soil Science Society of America Journal, vol. 67, no. 5, pp. 15241532, 2003.

[29] D. L. Karlen, E. G. Hurley, S. S. Andrews et al., "Crop rotation effects on soil quality at three northern corn/soybean belt locations," Agronomy Journal, vol. 98, no. 3, pp. 484-495, 2006.

[30] T. M. Zobeck, A. D. Halvorson, B. Wienhold, V. AcostaMartinez, and D. L. Karlen, "Comparison of two soil quality indexes to evaluate cropping systems in northern Colorado," Journal of Soil and Water Conservation, vol. 63, no. 5, pp. 329338, 2008.

[31] B. N. Moebius-Clune, H. M. Van Es, O. J. Idowu et al., "Longterm effects of harvesting maize stover and tillage on soil quality," Soil Science Society of America Journal, vol. 72, no. 4, pp. 960-969, 2008.

[32] E. H. Isaaks and R. M. Srivastava, An Introduction to Applied Geostatistics, Oxford University Press, New York, NY, USA, 1989. 

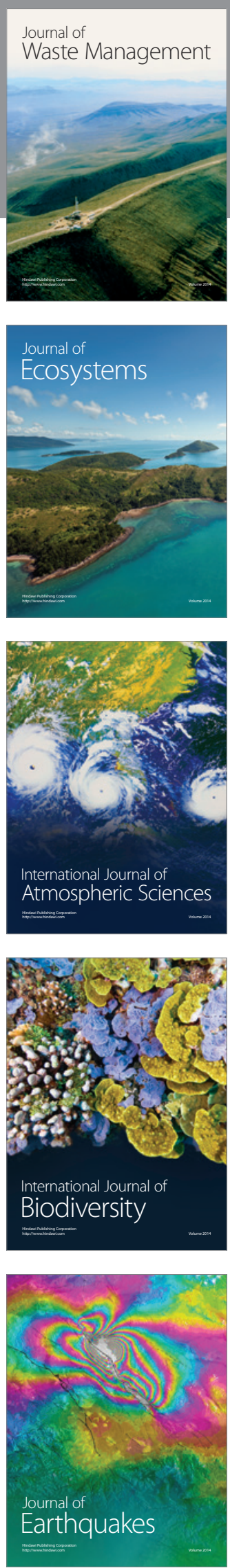
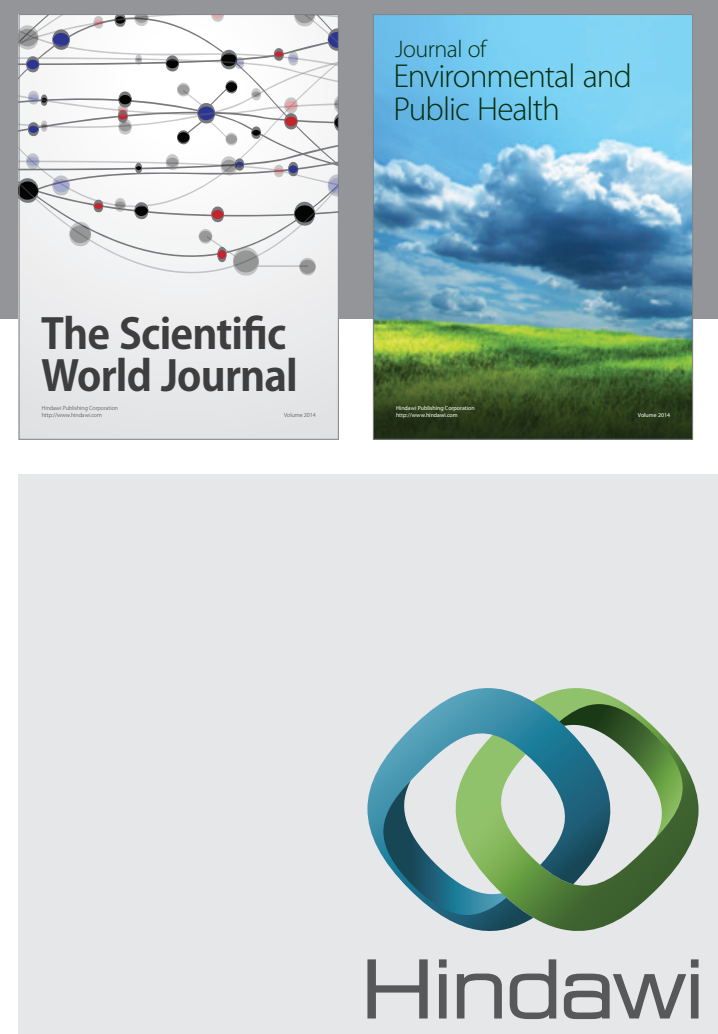

Submit your manuscripts at

http://www.hindawi.com
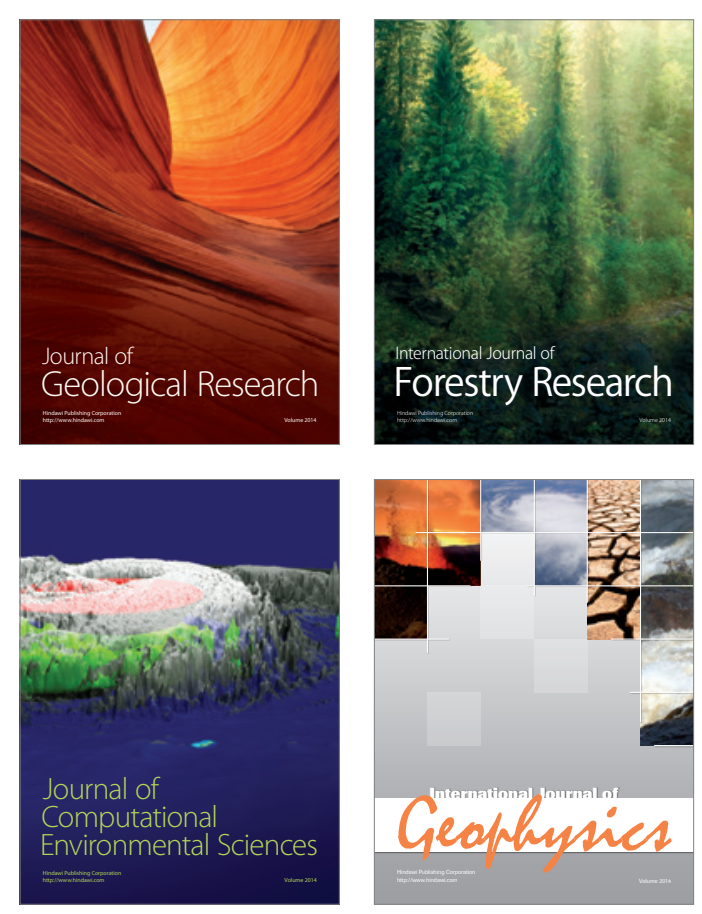
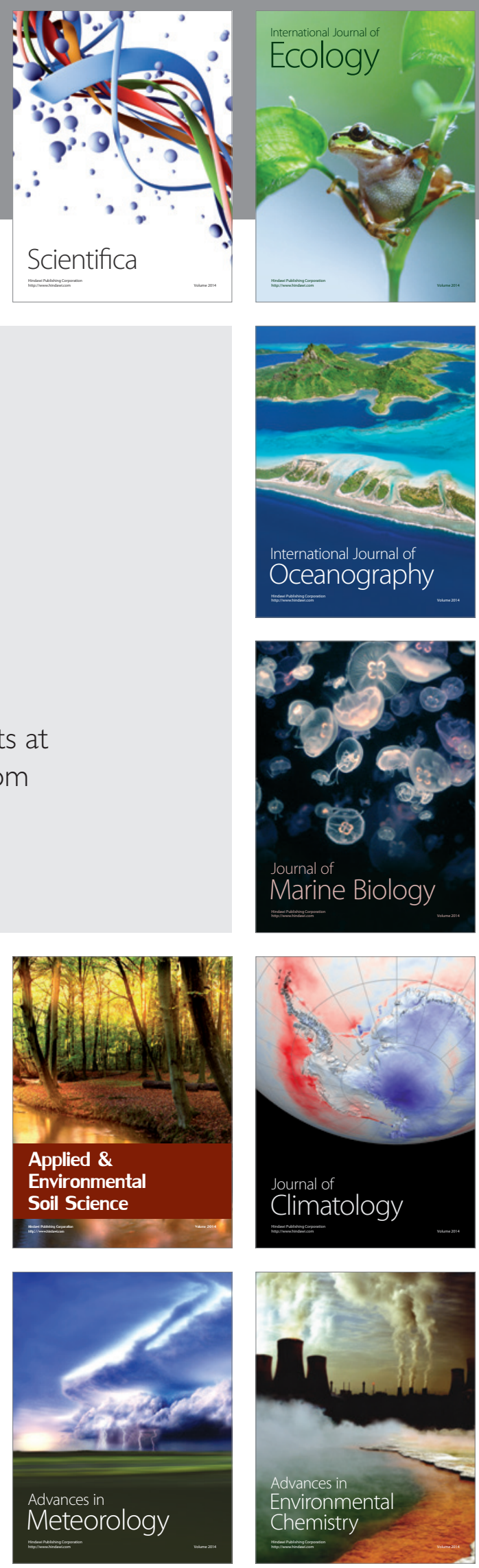